\section{The Potential of AMMI Analysis for Field Assessment of Musa Genotypes to Virus Infection}

\author{
Rodomiro Ortiz ${ }^{1}$ \\ International Institute of Tropical Agriculture, PMB 5320, Ibadan, Nigeria
}

Additional index words. banana streak virus, cucumber mosaic virus, epistasis, virus resistance, additive main effect multiplicative interaction

\begin{abstract}
Virus-like symptoms (due to banana streak virus, cucumber mosaic virus, or both) have been observed in plants of Musa hybrids (TMPx) and local landraces included in multilocational trials in sub-Saharan Africa. Virus-like symptom incidence in these multilocational trials was analyzed using the additive main effect multiplicative interaction (AMMI) model. There were significant differences in virus-like symptom incidence among environments, which was highest in the cool, rainy season (14\% to $42 \%)$ and lowest in the warm, dry season $(<\mathbf{1 0 \%})$. Genotypes showed significantly different responses to virus(es), which depended on the environment. There were no plants of AA and AAA bananas showing virus-like symptoms ( $0 \%$ incidence), whereas ABB cooking bananas and a cooking banana hybrid (ABB X AA) seldom showed virus-like symptoms $(<2 \%$ incidence). The AAB French plantains appeared to have a similar genotypic response to virus(es) (about $10 \%$ virus-like symptom incidence) and were regarded as less susceptible than the False Horn plantain 'Agbagba', which showed virus-like symptoms in most of the environments (average $21 \%$ incidence). Hence, 'Agbagba' should be considered a susceptible indicator host because it has a stable susceptible host response to Musa virus(es). Plantain hybrids (AAB X AA) showed virus-like symptoms; however, there were significant differences in genotypic response to the virus(es) among various hybrids $(11 \%$ to $60 \%$ ). Epistasis due to transgressive segregation may control the susceptibility of TMPX germplasm to Musa virus(es). The AMMI1 model revealed that an increase in clonal susceptibility resulted in a more unstable response to the virus. Similarly, phenotypic instability was associated with an increase in clonal resistance. Environments with very low (dry season) or very high (rainy season) incidence of virus-like symptoms had unstable virus expression. Scoring virus symptoms in cool environments with low rainfall and low potential evapotranspiration provided an unbiased assessment of genotypic response to Musa virus(es). The AMMI2 model showed that seasonal rather than locational diversity accounted for most of the interaction patterns. This finding may indicate a low level of strain differentiation in the region.
\end{abstract}

Occurrence of viruses affecting banana such as cucumber mosaic virus (CMV), banana bunchy top virus (BBTV), and banana streak virus (BSV) in several African countries has serious implications for the adoption of improved breeding materials and the safe movement of germplasm across national boundaries (Jones, 1994; Jones and IskraCaruana, 1994). Diseased plants have reduced

Received for publication 22 Nov. 1995. Accepted for publication 12 Apr. 1996. Paper No. IITA/95/ CP/15. I thank F. Gauhl, C. Pasberg-Gauhl, and D Vuylsteke (IITA) for data collection on virus incidence in multilocational trials. Also acknowledged is the cooperation of partners in African National Agricultural Research Systems for multilocational testing of Musa germplasm and the work of H.W Rossel, IITA's former core virologist, who initiated virus research in Musa at IITA. The cost of publishing this paper was defrayed in part by the payment of page charges. Under postal regulations, this paper therefore must be hereby marked advertisement solely to indicate this fact.

${ }^{1}$ Breeder/Geneticist and Leader, Plantain and $\mathrm{Ba}-$ nana Improvement Program, International Institute of Tropical Agriculture. International mailing address: IITA, c/o L.W. Lambourn and Co., Carolyn House, 26 Dingwall Road, CR9 3EE, England. growth and low vigor, resulting in poor yield due to small or absent bunches.

The International Institute of Tropical Agriculture (IITA) has developed tetraploid and diploid plantain and banana hybrids with resistance to black sigatoka (Mycosphaerella fijiensis Morelet) (Vuylsteke et al., 1993, 1995) and has an active breeding program involved in the further improvement of material for other production constraints (Ortiz and Vuylsteke, 1994). Given the serious effects of black sigatoka disease (Mobambo et al., 1993), it is of major importance that IITA's resistant material be evaluated by national programs. Multilocational trials have been carried out with cooperation of National Agricultural Research Systems (NARS) in eight countries of sub-Saharan Africa (Ortiz et al., 1995a, 1995b). Virus-like symptoms have been observed in some plants of hybrids and local landraces included in these trials, and samples taken from some of these plants tested positive, mainly for BSV, but also a few samples tested positive for CMV (B.E. Lockhart, personal communication; M.L. Iskra-Caruana, personal communication)

There are three prerequisites to the initiation of a virus resistance breeding program.
First, it must be possible to recognize the range of genotype-specific reactions to virus infection. Second, it is crucial that symptomless or tolerant plants can be distinguished from truly resistant genotypes, which necessitates a highly precise diagnostic test. Finally, it should be possible to identify the most abundant vectors of viruses so resistance to their feeding might also be targeted in the breeding program. The occurrence of viruses in multilocational trials has provided the means to assess genotypic responses of Musa germplasm to viral diseases present in sub-Saharan Africa.

The additive main effect multiplicative interaction (AMMI) model was developed to analyze trials with a focus on the genotype $\times$ environment interactions (Gauch, 1992). AMMI uses the analysis of variance (ANOVA) to study the main effects of genotypes and environments and principal component analysis (PCA) for the residual multiplicative interaction. Using the same method, Ortiz (1993) and Ortizetal. (1995b) analyzed bunch weights and host response-black sigatoka interactions in Musa trials, respectively. This paper reports the value of AMMI in the analysis of virus incidence in multilocational trials of plantain and banana.

\section{Materials and Methods}

Multilocational evaluation trials (MET) were conducted from 1991 to 1994 in three locations: the IITA stations at Ibadan (humid forest-savanna transition zone) and Onne (High Rainfall Station) in Nigeria, and Mbalmayo (Humid Forest Station) in Cameroon (Table 1). MET-1 was planted in 1991 and included eight tetraploid plantain and banana hybrids (hereafter TMPx and TMBx, respectively), three cooking bananas ('Cardaba', 'Fougamou', and 'Pelipita'), two known blacksigatoka-susceptible cultivars ('Agbagba' and 'Valery'), the triploid parental genotypes ('Bluggoe', 'Bobby Tannap', and 'Obino l'Ewai'), and diploid banana parental genotypes ('Calcutta 4' and 'Pisang lilin').

MET-2 was planted in 1992 and included 11 TMPx, one TMBx, three AAB plantains ('Agbagba', 'Bobby Tannap', and 'Obino l' Ewai'), two ABB cooking bananas ('Bluggoe' and 'Cardaba'), one AAA dessert banana ('Valery'), and two AA bananas ('Calcutta 4' and 'Pisang lilin'). This multisite trial involved the participation of 11 NARS and IITA stations in Ghana, Nigeria, and Cameroon (Table 1).

Each MET was carried out in a minimum of three locations using 18 to 20 genotypes (hybrids and landraces) planted in randomized complete-block designs (RCBD). At all sites, genotypes were represented by two replications each of five plants derived from axenic Musa tissue culture material. Cultural practices in each site were those recommended by Swennen (1990).

Banana viruses are associated with the following symptoms in Musa germplasm: dark and light green, whitish or yellow streaks on the leaves; leaf deformation; stunting; internal pseudostem necrosis; cigar leaf death (or top 
Table 1. Agro-ecological characteristics of the testing sites in multilocational trials (1991-94). Multilocational trials were planted twice in Ibadan, Mbalmayo, and Onne, while only once in the other locations.

\begin{tabular}{|c|c|c|c|c|c|c|c|c|c|c|}
\hline \multirow[b]{2}{*}{ Location } & \multirow[b]{2}{*}{ Lat. } & \multirow[b]{2}{*}{ Long. } & \multirow{2}{*}{\multicolumn{2}{|c|}{$\begin{array}{c}\text { Natural } \\
\text { vegetation }\end{array}$}} & \multirow[b]{2}{*}{ Soil } & \multirow{2}{*}{$\begin{array}{l}\text { Altitude } \\
\text { (masl) }\end{array}$} & \multirow{2}{*}{$\begin{array}{l}\text { Rainfall }^{2} \\
(\mathrm{~mm})\end{array}$} & \multirow{2}{*}{$\begin{array}{c}\text { Radiation } \\
\left(\mathrm{MJ} \cdot \mathrm{m}^{-2} \cdot \mathrm{year}^{-1}\right)\end{array}$} & \multicolumn{2}{|c|}{ Temp $\left({ }^{\circ} \mathrm{C}\right)$} \\
\hline & & & & & & & & & $\overline{\text { Min. }}$ & Max. \\
\hline Akure & $7^{\circ} 17^{\prime} \mathrm{N}$ & $5^{\circ} 14^{\prime} \mathrm{E}$ & DCS & Mild/hot farmland & Ferric Luvisols & 300 & $1536 \mathrm{U}(9)$ & 5322 & $12-22$ & $26-32$ \\
\hline Benin & $6^{\circ} 19^{\prime} \mathrm{N}$ & $5^{\circ} 36^{\prime} \mathrm{E}$ & LH & Marsh/swamp & Dystric Nitosols & 60 & 2034 U (10) & 5201 & $12-22$ & $27-33$ \\
\hline Bori & $6^{\circ} 01^{\prime} \mathrm{N}$ & $7^{\circ} 25^{\prime} \mathrm{E}$ & LH & Mild/hot farmland & Dystric Nitosols & 120 & $1883 \mathrm{U}(10)$ & 5129 & $11-23$ & $27-33$ \\
\hline Calabar & $4^{\circ} 58^{\prime} \mathrm{N}$ & $8^{\circ} 20^{\prime} \mathrm{E}$ & $\mathrm{LH}$ & Mangrove/swamp & Blank & 30 & $3017 \mathrm{U}(11)$ & 4980 & $12-23$ & $28-32$ \\
\hline Ibadan & $7^{\circ} 26^{\prime} \mathrm{N}$ & $3^{\circ} 54^{\prime} \mathrm{E}$ & DCS & Wood $/$ crop/grass & Ferris Luvisols & 150 & $1253 \mathrm{~B}(8)$ & 5285 & $12-23$ & $28-34$ \\
\hline Mbalmayo & $3^{\circ} 30^{\prime} \mathrm{N}$ & $11^{\circ} 42^{\prime} \mathrm{E}$ & LH & Tropical forest & Orthic Ferralsols & 730 & 1658 B (9) & 5213 & $12-19$ & $25-29$ \\
\hline Obrikon & & & LH & & Alluvial soils & & 2240 B (10) & & mean & $7 \pm 2.5$ \\
\hline Onne & $4^{\circ} 46^{\prime} \mathrm{N}$ & $7^{\circ} 10^{\prime} \mathrm{E}$ & $\mathrm{LH}$ & Mangrove/swamp & Thionic Fluvisols & 30 & $2502 \mathrm{U}(11)$ & 5060 & $12-23$ & $28-32$ \\
\hline Umudike & $5^{\circ} 31^{\prime} \mathrm{N}$ & $7^{\circ} 23^{\prime} \mathrm{E}$ & LH & Grass/crop/wood ${ }^{\mathrm{x}}$ & Dystric Nitosols & 120 & $2417 \mathrm{U}(10)$ & 5067 & $12-22$ & $27-32$ \\
\hline Warri & $5^{\circ} 34^{\prime} \mathrm{N}$ & $5^{\circ} 50^{\prime} \mathrm{E}$ & $\mathrm{LH}$ & Wood $/$ grass/crop & Thionic Fluvisols & 30 & $2714 \mathrm{U}(10)$ & 5190 & $12-22$ & $28-32$ \\
\hline
\end{tabular}

${ }^{\mathrm{z}} \mathrm{U}=$ unimodal, $\mathrm{B}=$ bimodal; number of rainy months in parentheses.

${ }^{\mathrm{y}} \mathrm{AEZ}=$ agroecological zone; $\mathrm{DCS}=$ derived and coastal savanna; $\mathrm{LH}=$ lowland humids.

${ }^{x}$ Regrowing wood.

dieback); and distortion of peduncle, bunch, and fruits (Jones, 1994; Jones and Lockhart, 1993; Lockhart, 1994; Niblett et al., 1994). Plants showing any of these symptoms were scored as virus-susceptible.

Data of virus incidence, based on visual assessment of symptom expression in the experimental fields, were analyzed following combined ANOVA and the AMMI model (Gauch, 1992). Such an approach is expected to facilitate the identification of potentially resistant germplasm and allow a preliminary study of host-plant $\times$ virus interactions across environments. Environments were defined as a combination of location $\times$ date of evaluation.

Repeatability (R) was individually calculated for each set of trials (MET-1 and MET2) from the ratio of the variance components as $\mathrm{R}=\sigma_{\mathrm{C}}^{2} /\left(\sigma_{\mathrm{CE}}^{2}+\sigma_{\mathrm{E}}^{2}\right)$, where $\sigma_{\mathrm{C}}^{2}$ is the interclonal (or genetic variance), $\sigma^{2}$ iE the variance of the clonal-environmental interaction, and $\sigma_{\mathrm{E}}^{2}$ is the environmental variance. $R$ measures the relative importance of each variance component in the phenotype and varies from 0 (i.e., no genetic variance) to infinity (i.e., nil environmental effect and nil genotype $\times$ environment interaction).

\section{Results and Discussion}

There was significant difference among environments in virus symptoms (Table 2), trending higher in the cool, rainy season $(14 \%$ to $42 \%$ ) and lower in the warm, dry season $(<10 \%)$. Virus-like symptoms in Musa can be caused by viruses that differ in epidemiology or by other factors than virus infection; thus, symptoms could have been affected in various ways by environmental conditions. Genotypic responses to virus(es) were significantly different among entries and dependent on the environment as shown by the significant environment $\times$ clone interaction (Table 2 ).

Bananas, of the species $M$. acuminata ('Calcutta 4', 'Pisang lilin', and 'Valery'), had plants without virus symptoms ( $0 \%$ incidence) in 33 environments of West and Central Africa. This finding suggests that these bananas are resistant to the virus(es). However, the AAA Cavendish banana 'Poyo' was susceptible to BSV and CMV in Cote d'Ivoire (Lassoudiere, 1974; Yot-Dauthy and Bove, 1966). These conflicting results suggest that

Table 2. Analysis of variance of virus-like symptom incidence in multilocational evaluation trials (MET) trials (based on individual clonal means at each environment) (West and Central Africa, 1992-94).

\begin{tabular}{|c|c|c|c|c|}
\hline \multirow[b]{2}{*}{ Source of variation } & \multicolumn{2}{|c|}{ MET-1 ${ }^{2}$} & \multicolumn{2}{|c|}{ MET-2y } \\
\hline & $\operatorname{SS}(\%)^{x}$ & MSE & SS (\%) & MSE \\
\hline Environments (E) & 11 & $1079.51^{* * * *}$ & 22 & $4000.17^{* * * *}$ \\
\hline Clones (C) & 59 & $6165.96^{* * * *}$ & 38 & $7925.06^{* * * *}$ \\
\hline $\mathrm{E} \times \mathrm{C}$ & 30 & $174.55^{* * *}$ & 40 & $386.47^{* * * *}$ \\
\hline Repeatability & \multicolumn{2}{|c|}{1.40} & \multicolumn{2}{|c|}{0.58} \\
\hline Mean $(\%)$ & \multicolumn{2}{|c|}{11} & \multicolumn{2}{|c|}{21} \\
\hline $\mathrm{SE}(\%)$ & \multicolumn{2}{|c|}{1} & \multicolumn{2}{|c|}{1} \\
\hline
\end{tabular}

${ }^{2}$ Eighteen entries: eight hybrids (4x), eight landraces (3x), and two bananas $(3 x)$ were scored in 19 environments.

yTwenty entries: 12 hybrids ( $4 x)$, six landraces ( $3 x)$, and two bananas $(2 x)$ were scored in 23 environments (nine in common with MET-1).

xPercentage of total variation in the sum of squares due to specific source of variation.

${ }^{* * *}$ Significantly different at $P \leq 0.001$.

the AA and AAA bananas tested in this set of multilocational trials might have expressed mechanisms that masked expression of virus symptoms or they had latent virus infection, with little or no symptom expression.

ABB cooking bananas, such as 'Bluggoe', 'Cardaba', 'Fougamou', and 'Pelipita', as well as TMPx 612-74 (a cooking banana hybrid derived from 'Bluggoe' $x$ 'Calcutta 4'), seldom showed virus-like symptoms $(<2 \%$ incidence). These genotypes might express a resistance mechanism that slows virus replication or movement in the host or could be tolerant to viral effects that produce symptoms in other genotypes.

We regarded the AAB French plantains 'Bobby Tannap' and 'Obino l' Ewai', which had a similar host response to the virus(es) ( $\approx 10 \%$ incidence), as less susceptible than the False Horn plantain 'Agbagba', which showed virus-like symptoms in most of the environments (average $21 \%$ incidence). All plantain hybrids showed virus-like symptoms, but there were significant differences among genotypes in incidence of symptoms. 597-4, TMPx 5489, TMPx 4698-1, TMPx 548-4, and TMPx 2637-49 were among the most susceptible plantain hybrids (>40\% virus incidence). TMPx 6930-1 was the least susceptible plantain hybrid, with a response similar to its parental plantain landrace 'Obino l' Ewai'. The other susceptible hybrids (TMPx 1112-1, TMPx 5511-2, TMPx 2796-5, TMPx 2481, TMPx 582-4, TMPx 1621-1, TMPx 1658-4) exhibited $23 \%$ to $35 \%$ incidence of virus. Because randomization differed at each site, the very highly significant value for genotypic variation among clones $(P<0.001)$ suggests a very low potential for escapes of virus infection.

The occurrence of transgressive segregation (i.e., the expression by offspring of traits beyond the limits of variation defined by the parents) in the genotypic response of the hybrids suggests that epistasis may be the main nonadditive gene interaction system controlling the susceptibility of TMPx germplasm to Musa virus(es). Epistatic gene interactions could have occurred following genetic combination after crossbreeding the susceptible plantain landraces and the diploid bananas. TMPx may have inherited gene(s) for susceptibility from maternal plantain genotypes, which enhanced the expression of virus susceptibility by interacting with genes inherited from the paternal banana genotype.

Repeatability (R) was larger in MET-1 than in MET-2 (Table 2), because relative genetic variation was larger in MET-1 than in MET-2 despite MET-2 having more diverse material. Nonetheless, the variance components of MET-2 likely are more reliable than those of MET-1 since an increase in the number of diverse environments results in less biased estimates of statistical parameters. Hence, AMMI analysis was performed only on the MET-2.

AMMI model 1 (Fig. 1) captured $75 \%$ of the total variation: $60 \%$ due to the main clonal and environmental effects (in X axis) and 15\% due to their interaction effects ( $\mathrm{Y}$ axis). All the plantain hybrids derived from 'Obino l'Ewai' 


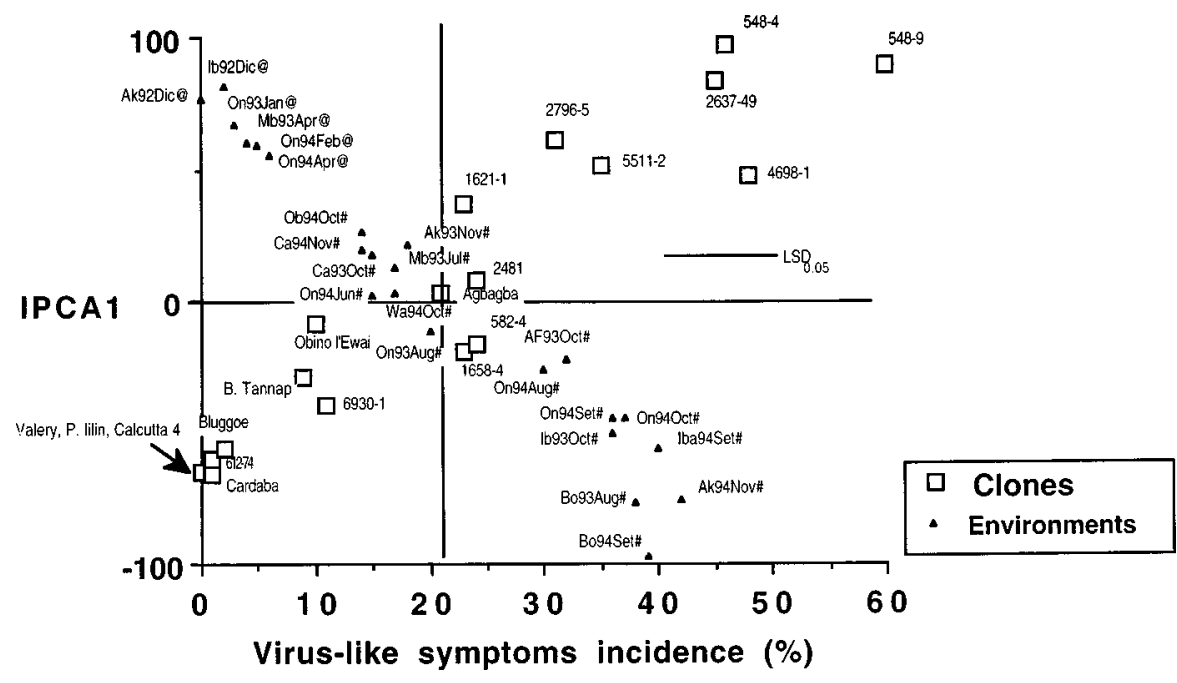

Fig. 1. AMMI1 model for incidence of virus-like symptoms in Musa germplasm in West and Central Africa. Environments are defined by alpha-numerical codes using two symbols to indicate locations followed by year (two digits) and month abbreviation. Locations codes are Akure (Ak), Assin-Fosu (AF), Benin (Be), Bori (Bo), Calabar (Ca), Ibadan (Ib), Mbalmayo (Mb), Obrikon (Ob), Onne (On), Umudike (Um), and Warri (Wa). Rainy environments are followed by the symbol\#, while dry environments are followed by the symbol@.

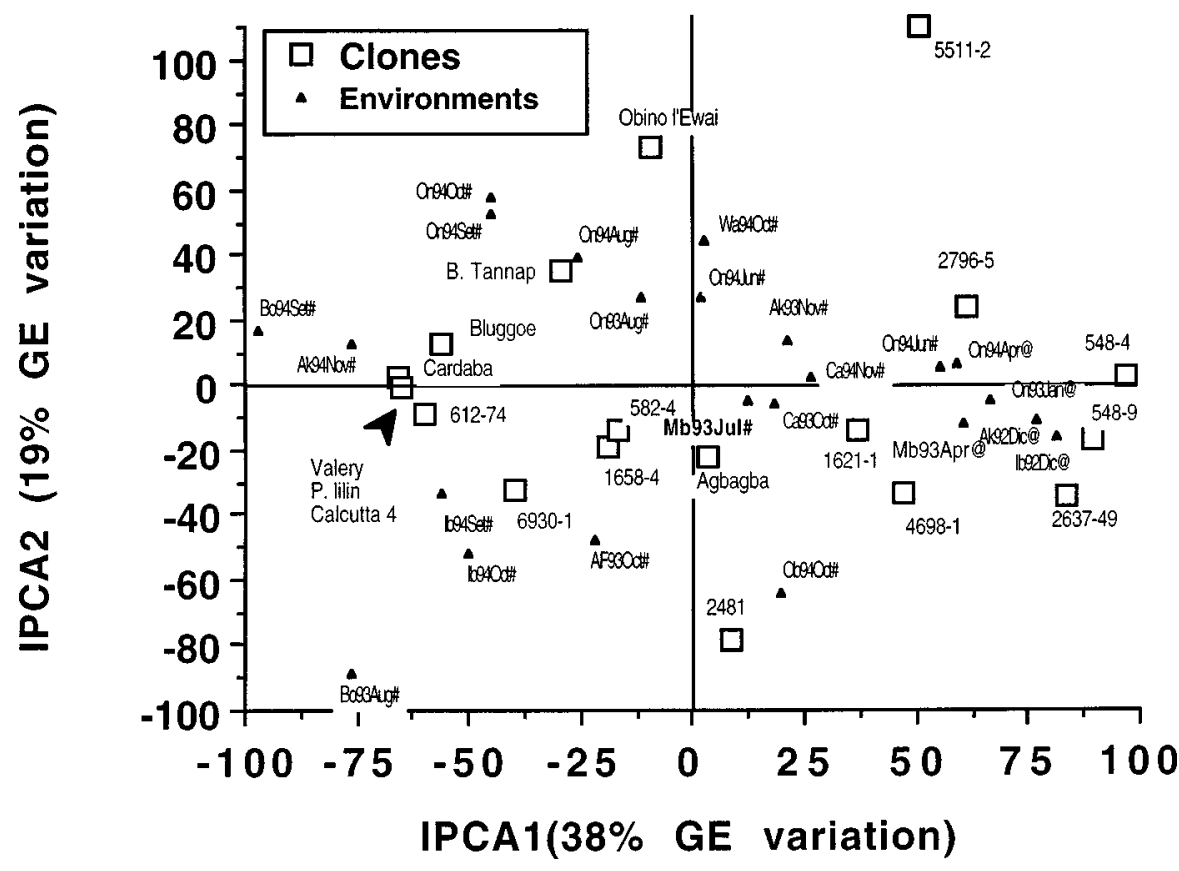

Fig. 2. AMMI2 model for incidence of virus-like symptoms in Musa germplasm in West and Central Africa. Environments defined as indicated in Fig. 1.

$x$ 'Calcutta 4' (except TMPx 6930-1) and TMPx 2796-5, a hybrid of 'Bobby Tannap' $x$ 'Pisang lilin', are in the highly unstable susceptible quadrant (upper right). Conversely, their pseudo-reciprocals TMPx 582-4('Bobby Tannap' $x$ 'Calcutta 4') and TMPx 1658-4 ('Obino l'Ewai' x 'Pisang lilin') were close to the center. These findings support the epistatic genetic model for virus susceptibility since clones with related pedigrees (i.e., half-sibs) were not grouped together. An increase in clonal susceptibility resulted in a more unstable response to the virus; similarly, phenotypic instability also was associated with an increase in clonal resistance (Fig. 1). Environments with very low (dry season) or very high (rainy season) virus incidence showed unstable expression of virus symptoms. 'Agbagba', with average susceptibility to Musa virus(es), had the most stable genotypic response to environmental change. Hence, this landrace could be considered a susceptible indicator host for further virus research.

The biplot of the interaction PCA (IPCA) scores show that $57 \%$ of the clone $\times$ environment (CE) interaction for virus incidence was explained by the IPCA axes (AMMI2 model) (Fig. 2). TMPx 582-4 and TMPx 1658-4 (near to 0.0 in Fig. 2) showed little CE interaction because their susceptible response to Musa virus(es) was stable across environments. Epistasis may affect not only the susceptible genotypic response of the hybrids to the virus but also their interaction with the environment, as revealed by the lack of grouping of maternal half-sibs in the AMMI2 biplot (Fig. 2 ). This response was expected, since nonadditive epistatic gene interactions are highly influenced by the environment.

Scoring virus symptoms visually at the IITA Humid Forest Station (Mbalmayo, Cameroon) in July 1993 (Mb93Jul) provided an unbiased assessment of genotypic response to the virus(es). Therefore, a predictable response based mainly on additive clonal and environmental effects could be expected in this environment (Mb93Jul close to the center in Fig. 2). Phenotypic correlations were very highly significant $(P<0.001)$ between the genotypic responses, based on virus symptom incidence, in the trials at M'Balmayo-July 1993 and across environments $(r=0.81$ and $r$ $=0.91$ for MET -1 and MET-2, respectively). Cool environments with low rainfall and low potential evapotranspiration, such as that of Mbalmayo in July 1993, may be optimal for screening the response of Musa germplasm to virus(es) based on visual symptoms.

The results show the value of AMMI analysis for field assessment of Musa landraces and hybrids to virus infection in multilocational trials. Environmental conditions clearly play a significant role in the expression of virus-like symptoms in Musa. Furthermore, the significant $\mathrm{CE}$ interaction could have been interpreted as a warning signal for strain differentiation at the various testing sites. However, the AMMI2 biplot clearly shows that seasonal rather than locational diversity accounts for most of the interaction patterns (Fig. 2). Nevertheless, more research will be required to establish in detail host-plant virus interaction, which should take into account critical aspects of plant virus biology and epidemiology.

Likewise, reliable techniques for specific identification of the virus involved are needed, since symptoms caused by several virus sometimes are very similar (Jones and Lockhart, 1993). Moreover, plants with latent virus infection may not show symptoms (Jones, 1994). Recently, scientists of the John Innes Centre (U.K.) and IITA have designed PCR-specific primers from the BSV sequence that produce a single amplification product (Crouch et al., 1996). In addition, a nonradioactive digoxigenin (DIG)-labeled probe has been generated from the entire BSV genome. By combining PCR and hybridization with a DIGprobe, it has been possible to ensure both sensitivity and specificity of BSV detection. Therefore, this sensitive diagnostic tool for virus detection and AMMI analysis will help Musa breeders know what kind of virus resistance should be chosen for the genetic improvement of plantain and banana.

\section{Literature Cited}

Crouch, J.H., R. Ortiz, H.K. Crouch, G. Dahal, J. d'A. Hughes, B.V. Ford-Lloyd, E.C. Howell, H.J. Newbury, G. Harper, R. Hull, and R.L. Jarret. 1996. Utilization of molecular techniques in support of plantain and banana improvement. In: Abstracts of the First International Confer- 
ence on Banana and Plantains for Africa, Kampala, Uganda, 14-18 Oct. 1996. MusAfrica 10. (Abstr.) (In press.)

Gauch, H.G. 1992. Statistical analysis of regional yield trials: AMMI analysis of factorial designs. Elsevier, Amsterdam.

Jones, D. 1994. Risks involved in the transfer of banana and plantain germplasm, p. 85-98. In: D. Jones (ed.). The improvement and testing of Musa: A global partnership. Proc. Global Conf. of the Intl. Musa Testing Program, San Pedro Sula, Honduras, 27-30 Apr. 1994. INIBAP, Montpellier, France.

Jones, D. and B.E. Lockhart. 1993. Banana streak disease. Fact sheet 1. INIBAP, Montpellier, France.

Jones, D. and M.L. Iskra-Caruana. 1994. Screening banana and plantain germplasm at INIBAP's virus indexing centers, p. 99-105. In: D. Jones (ed.). The improvement and testing of Musa: A global partnership. Proc. Global Conf. of the Intl. Musa Testing Program, San Pedro Sula, Honduras, 27-30 Apr. 1994. INIBAP, Montpellier, France.

Lassoudiere, A. 1974. La mosaique dite "a tirets" du bananier "Poyo" en Cote d'Ivoire. Fruits 29:349_ 357.
Lockhart, B.E. 1994. Banana streak virus, p. 19-20. In: R.C.Ploetz, G.A.Zentmyer, W.T. Nishijima, K.G. Rohrbach, and H.D. Ohr (eds.). Compendium of tropical fruit diseases. APS Press, St. Paul, Minn.

Mobambo, K.N., D. Vuylsteke, F. Gauhl, R. Ortiz, C. Pasberg-Gauhl, and R. Swennen. 1993. Yield loss in plantain from black sigatoka leaf spot and field performance of resistant hybrids. Field Crops Res. 35:35-42.

Niblett, C.L., S.S. Pappu, J. Bird, and R. Lastra. 1994. Infectious chlorosis, mosaic and heart rot, p. 18-19. In: R.C. Ploetz, G.A. Zentmyer, W.T. Nishijima, K.G. Rohrbach, and H.D. Ohr (eds.). Compendium of tropical fruit diseases. APS Press, St. Paul, Minn.

Ortiz, R. 1993. Additive main effects and multiplicative interaction (AMMI) model for analysis of Musa yield trials. MusAfrica 2:4-5.

Ortiz, R., J. Okoro, A.N. Agbor, A.N. Nwogu, and A. Lawrence. 1995a. MET-2: Multilocational testing of hybrid Musa germplasm at IITA and NARS sites in southeastern Nigeria and Cameroon. MusAfrica 6:18-20.

Ortiz, R. and D. Vuylsteke. 1994. Future strategy for Musa improvement at IITA, p. 40-42. In: Proc. of Musa Breeder's Consortium, San Pedro Sula, Honduras, 2-3 May 1994. INIBAP, Montpellier, France.

Ortiz, R., D. Vuylsteke, J. Okoro, R.S.B. Ferris, B. Dumpe, R. Apanisile, E. Foure, C. Jenny, O.B. Hemeng, D.K. Yeboah, B.A. Adelaja, O.B. Arene, F.E.O. Ikiediugwu, A.N. Agbor, A.N. Nwogu, G.O. Kayode, I.K. Ipinmoye, S. Akele, and A. Lawrence. 1995b. Genotypic responses of Musa germplasm to black sigatoka disease in West and Central Africa. MusAfrica 6:1618

Swennen. R. 1990. Plantain cultivation under West African conditions: A reference manual. IITA, Ibadan, Nigeria.

Vuylsteke, D., R. Ortiz, R.S.B. Ferris, and R. Swennen. 1995. PITA-9: A black sigatoka resistant hybrid from the 'False Horn' plantain gene pool. HortScience 30:395-397.

Vuylsteke, D., R. Swennen, and R. Ortiz. 1993. Registration of 14 improved tropical Musa plantain hybrids with black sigatoka resistance. HortScience 28:957-959.

Yot-Dauthy, D. and J.M. Bove. 1966. Mosaique du bananier. Identification et purification de diverses souches du virus. Fruits 21:449-465. 